\section{Katon Macieja Kazimierza Sarbiewskiego (Lyr. II 6) i exercitia Seneciana}

s. $1-24$

www.ejournals.eu/

Terminus

\author{
Abstract \\ Maciej Kazimierz Sarbiewski's Cato (Lyr. II 6) and exercitia Seneciana
}

The starting point for the research presented in this article was an attempt to trace the literary tradition which inspired the creation of the lyrical subject and the titular figure of Maciej Kazimierz Sarbiewski's ode II 6 (Cato Politicus). The presence of this name implies that the intertextual dimension of the poem should be taken into account in its interpretation, hence, the author of this article assumed that the question of the literary tradition should be addressed before a hypothesis about the meaning of the poem is put forth.

A review of Sarbiewski's potential sources of inspiration - primarily works that were included in the basic and supplementary reading lists in Jesuit colleges - brings satisfactory results. It turns out that the ancient author who often mentions Cato the Younger is Seneca Philosophus, moreover, there are numerous similarities between some passages in his works and ode II 6. Sarbiewski seems to have been especially inspired by his Epistulae morales ad Lucilium, and also by the Senecan Consolationes. However, rather than refer to the views attributed by Seneca explicitly to Cato, the Polish poet explores the thoughts of the Philosopher himself, possibly assuming that the views of the politician and the philosopher were similar; this assumption could be justified by the fact that Seneca not only repeatedly expresses highest praise of the republican hero, but he also openly recommends to treat Cato Uticensis as a role model.

These issues are discussed in the first part of this paper. In the second part, the author compares selected passages from Seneca's works and two poems (II 5 and II 7) adjacent to the ode Cato Politicus. The comparison shows that the convergences discussed above are not incidental. On the contrary, there is a series of Sarbiewski's odes inspired by Seneca, and therefore the Roman philosopher and tragedian can be considered the next, after Horace, master of the Jesuit poet. It is postulated that these inspirations deserve more recognition in further studies on Sarbiewski's poetry, as they may be helpful in the interpretation of some problematic passages of his odes.
Maciej

Kazimierz

Sarbiewski; odes II 6 , II 5 , II 7;

Cato the Younger; reception of Seneca the Younger 
Dotychczas nie sformułowano explicite pytania o tradycję literacką, która mogłaby stanowić inspirację dla specyfiki kreacji podmiotu mówiącego oraz brzmienia nazwiska umieszczonego w nagłówku ody Cato Politicus (II 6) Macieja Kazimierza Sarbiewskiego - tymczasem właśnie obecność owego nazwiska pociąga za sobą konieczność uwzględnienia w interpretacji intertekstualnego wymiaru wiersza. Co więcej, autorzy starożytni upamiętnili dwóch sławnych Katonów, tym bardziej niezbędna wydaje się więc kwerenda zmierzająca do wskazania możliwych źródeł inspiracji poety. Celowe byłoby przy tym zawężenie wyników poszukiwań do grupy tekstów, których znajomość ze strony autora i jego projektowanej publiczności literackiej należałoby założyć w pierwszej kolejności - ze specjalną uwagą powinno się zatem przewertować dzieła uwzględnione w wykazie ich lektur szkolnych. Kwerenda taka w istocie przyniesie satysfakcjonujące rezultaty, nie tylko bowiem pozwoli wyjaśnić sformułowaną wyżej kwestię, ale jednocześnie ujawnić kolejnego - po Horacym - niekwestionowanego mistrza autora Liryków: Senekę Młodszego. Na fakt recepcji jego myśli przez Sarbiewskiego naprowadzają już wcześniejsze liczne uwagi wnikliwych czytelników poety ${ }^{\mathbf{1}}$, dotąd nie powstało jednak systematyczne zestawienie wybranych utworów i miejsc. Prezentowana tutaj próbka takiego zestawienia dowodzi natomiast, że chodzi o inspiracje nieokazjonalne, których uwzględnienie może dostarczyć wskazówek co do literalnego znaczenia wielu fraz i szeroko rozumianej egzegezy wierszy, a ponadto co do zasady regulującej stosunek do ćwiczeń i zaleceń moralnych, które chrześcijański twórca powtarza za swym pogańskim wzorcem.

Do ukształtowania i transmisji legendy ${ }^{2}$ Katona Utyckiego jako pierwsza przyczyniła się być może słynna mowa Arpinaty Cato, propagująca wizerunek republikańskiego herosa, który próbował zanegować Cezar między innymi w swoim Anty-Katonie ${ }^{3}$. Treść tego zaginionego pisemka Cycerona przybliża ustęp jego listu do Attyka (Cicero Ad Atticum XII 4, 2) ${ }^{4}$ :

$1 \quad$ Przede wszystkim Piotra Urbańskiego i Elwiry Buszewicz, zob. P. Urbański, Między ignacjanizmem a neostoicyzmem, w: idem, Theologia fabulosa. Commentationes Sarbievianae, Szczecin 2000; E. Buszewicz, Maciej Kazimierz Sarbiewski - „Ody” refleksyjne i religijne, w: Lektury polonistyczne, red. J.S. Gruchała, Kraków 1999; E. Buszewicz, Sarmacki Horacy i jego liryka. Imitacja - gatunek - styl. Rzecz o poezji Macieja Kazimierza Sarbiewskiego, Kraków 2006; szczegółowe wskazówki zob. dalej w tym artykule, przyp. $14,27,40,46,48,56,76$.

$2 \quad$ Legenda ta miała długi żywot - także w literaturze polskiej, o czym możemy się przekonać, dokonując wraz z tytułowym bohaterem Pana Tadeusza przeglądu malowideł zdobiących izby dworku w Soplicowie: „I też same portrety na ścianach wisiały./ Tu Kościuszko w czamarce krakowskiej, z oczyma/ Podniesionymi w niebo, miecz oburącz trzyma;/ Takim był, gdy przysięgał na stopniach ołtarzów,/ Że tym mieczem wypędzi z Polski trzech mocarzów,/ Albo sam na nim padnie. Dalej w polskiej szacie/ Siedzi Rejtan żałośny po wolności stracie,/ W ręku trzyma nóż, ostrzem zwrócony do łona,/ A przed nim leży Fedon i Żywot Katona", A. Mickiewicz, Pan Tadeusz, oprac. K. Górski, Warszawa 1983, ks. 1, w. 56-64. Za przypomnienie mi przed kilkoma laty tej wzmianki u polskiego klasyka dziękuję mojemu ówczesnemu studentowi, Panu Zbigniewowi Przybyłce.

3 Zob. R.J. Goar, The Legend of Cato Uticensis from the First Century B.C. to the Fifth Century A.D. With an Appendix on Dante and Cato, Bruxelles 1987, s. 14-18.

$4 \quad$ Cyceron o mowie tej wspomina kilkakrotnie, zob. Cicero Orator 35; Ad Atticum XII 40, 1 i XIII 46, 2; być może także w Ad Atticum XII 44, 1 i De divinatione II 1, 3. 


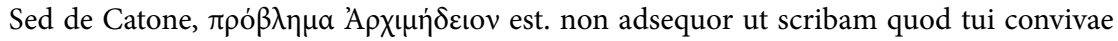
non modo libenter sed etiam aequo animo legere possint; quin etiam si a sententiis eius dictis, si ab omni voluntate consiliisque quae de re publica habuit recedam $\psi \mathbf{\imath} \lambda \tilde{\omega} \varsigma q u e$ velim

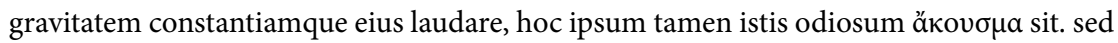
vere laudari ille vir non potest nisi haec ornata sint, quod ille ea quae nunc sunt et futura viderit et ne fierent contenderit et facta ne viderit vitam reliquerit.

[Ale co do Katona - to archimedesowa kwestia. Nie zdołam napisać nic takiego, co by twoi stołownicy przeczytali, już nie mówię, że z ochotą, ale choćby bez wzburzenia. Przecież nawet gdybym pominął to, co mówił, całe jego oddanie dla rzeczypospolitej i dbałość o nią, nawet jeślibym chciał tylko sławić jego powagę i niezłomność, to przecież to właśnie będzie im nie w smak. Nie da się jednak należycie pochwalić tego człowieka, nie podkreślając, że on przewidział obecną i przyszłą sytuację i starał się do niej nie dopuścić, i żeby nie patrzeć, jak się urzeczywistni - pożegnał się z życiem] $]^{5}$.

Śladem Cycerona podążali inni uznani autorzy antyczni ${ }^{6}$, których dzieła włączono później do kanonu obowiązkowych i uzupełniających lektur w kolegiach jezuickich. Jeśli chodzi o literaturę czytaną podczas zajęć szkolnych, kanon ten objął ${ }^{7}$ - uwzględniam tylko zabytki, w których znajdujemy najbardziej panegiryczne wizerunki Porcjusza Młodszego - listy Arpinaty ${ }^{8}$, jego Brutusa, Paradoksy stoickie, Rozmowy tuskulańskie, O powinnościach, O granicach dobra i zła i mowy, w tym W obronie Sestiusza, a także Sprzysiężenie Katyliny Salustiusza, poezję Horacego oraz dzieła Wellejusza Paterkulusa i Waleriusza Maksymusa ${ }^{9}$. Na liście autorów

$5 \quad$ Wykaz źródeł cytatów z dzieł klasycznych znajduje się w bibliografii. Wszystkie tłumaczenia w tekście pochodzą od autorki.

6 Systematyczne zestawienie krótszych i dłuższych wzmianek o Katonie Młodszym oraz utworach mu poświęconych zob. R.J. Goar, The Legend of Cato Uticensis..., s. 13-100. Jak wynika z tego zestawienia, Katon jako wybitny przykład prawego męża, polityka uosabiającego cnoty republikańskie oraz doskonałego stoika szczególną estymą był darzony już po śmierci, a jeszcze w ostatnich latach republiki, jak również w pierwszym stuleciu pryncypatu, zatem w okresie, w którym w Rzymie wciąż żywe były sentymenty względem ideałów republikańskich (choć warto dodać, że Katona chwalono nie tylko w środowisku antycesarskiej opozycji). Świadectwa autorów pogańskich z ostatnich dekad I wieku n.e. oraz wieków II i III potwierdzają bardziej zróżnicowany stosunek do postaci Katona i zamieranie jego legendy.

7 Zob. zachowane zestawienia lektur z pierwszej połowy XVII wieku: Catalogus quinquennalis [1604-1608] oraz Catalogus perpetuus [1629-1934], w: G.M. Pachtler, Ratio studiorum et institutiones scholasticae Societatis Iesu per Germaniam olim vigentes collectae, concinnatae, dilucidatae, Berlin 1894, vol. 4, s. 6-12, 25-29; Catalogus triennalis [1614-1622], w: Ordinationes praepositorum generalium, provincialium, visitatorum et responsa Romana Provinciae Polonae et Litvaniae saeculis XVI-XVII data, Archivum Societatis Iesu Cracoviense, 496, s. 910-919.

8 Zob. wyżej oraz zestawienie wzmianek w innych, wcześniejszych listach w: R.J. Goar, The Legend of Cato Uticensis..., s. 13 i przyp. 1. Jak podkreśla Goar (ibidem, s. 13), przed śmiercią Katona w listach Arpinaty pojawia się zarówno ton laudacyjny wobec prawości i odwagi Porcjusza, jak i krytyka jego nieustępliwości czy krótkowzroczności politycznej.

9 Zob. wzmianki: Cicero Brutus 118 (pochwała Katona jako doskonałego stoika i znakomitego mówcy); Cicero Paradoxa stoicorum praef. (o Katonie jako doskonałym stoiku i o jego wystąpieniach, w których 
pominiętych w zachowanych zestawieniach lektur podstawowych, lecz widniejących w spisie zalecanych wydań i komentarzy do tychże lektur, a także w wykazach literatury uzupełniającej (libri caniculares) lub rekomendowanej jako dodatkowe źródło wiedzy ${ }^{10}$ znalazły się nazwiska Seneki (jako autora m.in. Listów moralnych do Lucyliusza i Konsolacji), Lukana oraz Plutarcha (ze wskazaniem m.in. na jego Żywoty) ${ }^{11}$.

Kanon ten mógł sprzyjać przenikaniu elementów legendy utyckiego bohatera do literatury powstałej w kręgu profesorów kolegiów jezuickich i ich wychowanków. Nie powinno zatem dziwić, gdyby również Sarbiewski upamiętnił tę właśnie postać, oddając jej głos w Cato Politicus (II 6) ${ }^{12}$, jedynej swojej odzie reprezentującej lirykę roli - jak wskazuje Piotr Urbański ${ }^{13}$. Badacz nie podejmuje wprost zagadnienia identyfikacji Katona Sarbiewskiego z określoną postacią antycznego świata czy bohaterem literackim. Przyjmując szerszą perspektywę badawczą, nie stawia też pytania o interpretacyjne konsekwencje wynikające z takiej identyfikacji, jakkolwiek jako

odwoływał się do konceptów identyfikowanych jako stoickie); Cicero Tusculanae disputationes V, 4 (o Katonie jako postaci własnym istnieniem potwierdzającej istnienie cnoty); Cicero De officiis I, 112 (w tonie pochwalnym o powadze, gravitas, i nieustępliwości Katona w kontekście jego wyboru między śmiercią a uległością wobec tyrana); Cicero De finibus bonorum et malorum III, 6-7 i IV, 44 (chwalona jest tutaj cnota i erudycja Katona jako rozmówcy Cycerona wprowadzonego w księgach III i IV, w których kolejno sam prezentuje poglądy stoickie dotyczące tematyki omawianej w całym dialogu, a następnie wysłuchuje polemiki Arpinaty); Cicero Pro Sestio 12; 60-63 (o prawości i odwadze Katona jako polityka); Sallustius Catilinae coniuratio 52-54 (przytoczona mowa Katona, za pomocą której przekonał opornych członków senatu do zastosowania drastycznych środków przeciwko uczestnikom spisku; Salustiusz umieszcza tu również charakterystykę Katona - jako człowieka wielkiego ducha i autorytetu, znakomitego mówcy, o nienagannej opinii, skromnego, przede wszystkim zaś surowego: „[...] at Catoni studium modestiae, decoris, sed maxume severitatis erat”); Horatius Carmina I 12, 35-36; II 1, 21-24; Horatius Epistulae I 19, 12-14 (o nieugiętości, surowości i chwalebnej śmierci Katona); Velleius Paterculus II, 35 (o nieskazitelności, sprawiedliwości, suwerenności Katona wobec losu); Valerius Maximus II 10, 7-8; III 1, 2; III 2, 14; III 4, 6; III 6, 7; IV 1, 14; IV 3, 2; IV 3, 12; IV 6, 5; VI 2, 5; VII 5, 6; VIII 7, 2; VIII 15, 10 (o nieugiętości, skromności, uczciwości, wstrzemięźliwości, oczytaniu, popularności, nieskazitelnej virtus, chwalebnej śmierci Katona; tu także wzmianka o przegranej Porcjusza w wyborach na pretora - jako ujmie dla samego urzędu, lecz nie dla przegranego). Zob. też: R.J. Goar, The Legend of Cato Uticensis..., s. 13-35. Pomijam tu Eneidę Wergiliusza, również czytaną na zajęciach szkolnych, w której (Vergilius Aeneis VI, 841; VIII, 670) występują dwie wzmianki o Katonie (jako mężu wielkim i predestynowanym do roli prawodawcy tych, którzy są pii), jednak nie jest pewne, do którego Katona należałoby je odnieść; Serwiusz (Servius ad loc.) uznaje, że chodzi tu o Katona Starszego.

Zob. Catalogus commentariorum 1604, Libri caniculares [1604], Index horum librorum, qui non solum praelectiones in scholis adiuvant, sed etiam plurimum conferunt ad eruditionem comparandam [1604], w: G.M. Pachtler, Ratio studiorum..., s. 15-16, 3, 19.

Zob. Lucanus II, 239-391; VI, 311 i 790; IX, 19-889 (niezwykle wyidealizowany wizerunek Katona jako człowieka nieskazitelnego moralnie, godnego deifikacji, doskonałego stoika stojącego ponad losem i jednocześnie całkowicie oddanego ojczyźnie, publicznemu dobru, republikańskiej wolności); Plutarchus Cato Minor; por. też: R.J. Goar, The Legend of Cato Uticensis..., s. 36-48, 65-72. Na temat wzmianek u Seneki zob. dalej.

12 Korzystam z edycji: M.K. Sarbiewski, Liryki oraz Droga rzymska i fragment Lechiady, przeł. T. Karyłowski, oprac. M. Korolko przy współudziale J. Okonia, Warszawa 1980.

13 P. Urbański, Między ignacjanizmem a neostoicyzmem, s. 105. 
podpowiedź można potraktować jego wskazanie na simile do ody II 6 - ustęp listu Seneki dotyczący obojętności Porcjusza Młodszego w starciu z przeciwnościami $\operatorname{losu}^{\mathbf{1 4}}$ (Seneca Epistulae 71, 11): „W dniu swej porażki wyborczej grał, w nocy, której miał zginąć, czytał; tyle samo przejął się utratą pretury, co życia; wytłumaczył sobie, że wszystko, co mu się przydarzy, powinien znieść"15. Seneka wzmianki na ten sam temat czyni zresztą częściej - w Consolatio ad Helviam $(13,5)$ oraz w innym liście (Epistulae 104, 33), bogatszym w szczegóły: „Przekonaj się, że można wzgardzić zaszczytem i niełaską: w dniu, w którym przepadł w wyborach, grał w piłkę" ${ }^{16}$. O grze Katona w piłkę (ale po przegranej w wyborach na konsula, po której zrezygnował ze starań o preturę) wzmiankuje też Plutarch (Cato Minor 49-50).

Słowa bohatera wiersza Sarbiewskiego - bez żalu przekaże zaszczytne funkcje zastępcy, „Cum Superi volent” [„kiedy bogowie zechcą”] (Lyr. II 6, 25-32) - można w istocie odnieść do reakcji Porcjusza Młodszego na wiadomość o przegranej w wyborach. Nie byłoby jednak błędem założenie, że chodzi tu o zadeklarowanie postawy pożądanej u każdego republikańskiego męża stanu, który winien przestrzegać zasady kadencyjności urzędów publicznych ${ }^{\mathbf{1 7}}$. Metafora widza bawiącego się („ridens e media plebe”) spektaklem granym przez kolejnych tymczasowych aktorów życia publicznego w purpurze i togach (Lyr. II 6, 29-36) niedokładnie też odpowiada obrazowi Katona grającego w piłkę po jednej ze swoich porażek wyborczych - tym bardziej że skądinąd mocno podkreślane są (m.in. przez Plutarcha i samego Senekę ${ }^{18}$ ) zaangażowanie Porcjusza Młodszego w sprawy publiczne, a także jego surowość i powaga. Z kolei w wersach 1-24 ody II 6, w których mówiący przyznaje pierwszeństwo zaletom ducha przed bogactwem, choć nie odmawia przyjęcia zasłużonych godności,

$14 \quad$ Ibidem, s. 106-107.

15 „Quo die repulsus est lusit, qua nocte periturus fuit legit; eodem loco habuit praetura et vita excidere; omnia quae acciderent ferenda esse persuaserat sibi”.

16 „Vides honorem et notam posse contemni: eodem quo repulsus est die in comitio pila lusit”.

17 Por. np. „Regio imperio duo sunto, iique < a > praeeundo iudicando consulendo praetores iudices consules apellamino; militiae summum ius habento, nemini parento; ollis salus populi suprema lex esto. Eundem magistratum ni interfuerint decem anni ne quis capito; aevitatem annali lege servanto. Ast quando duellum gravius discordiaeve civium escunt, oenus ne amplius sex menses, si senatus creverit, idem iuris quod duo consules teneto [...]”. [„Najwyższe urzędy mają być kolegialne, a sprawujący je mają nosić miano pretorów, sędziów i konsulów - od przewodzenia, sądzenia i radzenia. Ma im przysługiwać najwyższa władza wojskowa i nikomu nie mają podlegać; ich najwyższą troską ma być dobro państwa. Nikt nie może obejmować tego samego urzędu częściej niż co dziesięć lat; należy przestrzegać rocznego okresu sprawowania funkcji. A gdy wybuchnie wojna i wewnętrzne zamieszki w państwie, władza, którą kiedy indziej sprawuje dwóch konsulów, ma należeć do jednego - nie dłużej niż przez sześć miesięcy i o ile uchwali tak senat”], Cicero De legibus III, 8-9.

18 Zob. Plutarchus Cato Minor 1-70 oraz Seneca Epistulae 95, 69-71; por. też miejsce, w którym Seneka odradza adresatowi tak wielkie zaangażowanie w sprawy publiczne, jakie cechowało Katona - Seneca Epistulae 14, 12-14. Według Plutarcha (Cato Minor 42-43), gdy Katon przegrał w staraniach o preturę, był jak najdalszy od demonstrowania swojego dystansu wobec biegu spraw politycznych. Zob. także w przyp. 9 w tym artykule zestawienie autorów wspominających o Katonie. Lukan (II, 372-378) i Plutarch (Cato Minor 53) podają też m.in., że od czasu wybuchu wojny domowej Katon nie uśmiechnął się już, nie golił ani nie strzygł. 
można doszukiwać się inspiracji zarówno wizerunkiem Katona Utyckiego przekazanym przez tradycję, jak i literackim obrazem jego pradziada, Katona Starszego (234-149), znakomitego republikańskiego polityka słynącego z samodyscypliny ${ }^{19}$. Według Plutarcha (Cato Maior 2) Porcjusz Starszy umocnił się w swej pogardzie dla bogactwa i podziwie dla cnót jeszcze w młodości, odwiedzając znajdujące się w sąsiedztwie skromne gospodarstwo Maniusza Kuriusza Dentata (konsul w latach 290, 275, 274 p.n.e.), zwycięskiego wodza i triumfatora, który po złożeniu dyktatury powrócił do pracy na roli. W tymże gospodarstwie mieli go odwiedzić posłowie samniccy. Próbowali go przekupić, Kuriusz odparł jednak, że przy jego trybie życia nie potrzebuje złota i bardziej od jego posiadania ceni sobie podbicie jego posiadaczy ${ }^{\mathbf{2 0}}$.

W utworze Sarbiewskiego brak ponadto ułatwiającego identyfikację nawiązania do szczególnie eksponowanej w literaturze antycznej ${ }^{21}$ sceny samobójczej śmierci Katona, którą ostatecznie dowiódł wierności wyznawanej koncepcji virtus - jakkolwiek pominięcie to można by usprawiedliwić w odwołaniu na przykład do wypowiedzi Justusa Lipsjusza (1547-1606). Jeden z najwybitniejszych humanistów swoich czasów w ocenie samobójstwa Katona przyjął stanowisko wytyczone już przez wczesnych autorów chrześcijańskich ${ }^{22}$ : „Ale hart, jaki okazał nawet w chwili śmierci, przemilczę, bo różnie można go tłumaczyć, a wiedzmy, że nasza religia go potępi" $^{23}$. Warto nadmienić, że znający opracowanie Plutarcha Lipsjusz, którego dzieła również zalecano w kolegiach w ramach lektury uzupełniającej ${ }^{\mathbf{2}}$, w cytowanych tu Monita et exempla politica jednego i drugiego Katona stawia za wzór,

19 Zob. zwłaszcza Plutarchus Cato Maior 3-11. Określenie „Politicus” u Sarbiewskiego nie stanowi w tym przypadku wskazówki naprowadzającej, jaką byłoby użycie przymiotników „Censorius” (w odniesieniu do Katona Starszego, który pełnił urząd cenzora) lub „Uticensis” (w odniesieniu do Katona Młodszego). „Politicus”, przydomek, który skądinąd można uznać za znaczący, zdaje się tu odsyłać jedynie do postawy bohatera w konfrontacji z szeroko rozumianymi sprawami polityki, nie służąc rozstrzygnięciu kwestii, o którego Katona polityka chodzi. W tym miejscu warto wskazać, że wiele imion i/lub nazwisk fikcyjnych adresatów wierszy Sarbiewskiego można spróbować odczytywać jako nazwy znaczące. Na przykład imion adresata omawianej niżej ody II 7 Ad Publium Memmium, mimo że chodzi tu o jedno z nazwisk rzymskich i popularne rzymskie imię, nie należy raczej odnosić do żadnej konkretnej postaci świata antycznego. Można je natomiast uznać za naprowadzające na znaczenia zawarte np. w przymiotnikach publicus 'powszechny' oraz memor 'pamiętający' i potraktować jako wskazujące na „każdego, kto pamięta”, ewentualnie kto „powinien zapamiętać”. Wcześniej, m.in. w odniesieniu do adresata Lyr. III 12 Ad Aurelium Fuscum, celną interpretację na podstawie etymologii nazwy zaproponowała Elwira Buszewicz (Sarmacki Horacy i jego liryka..., s. 200). Por. także uwagi w przyp. $76 \mathrm{w}$ tym artykule. Por. też: Valerius Maximus IV 3, 5. Zob. s. 3 i przyp. $9 \mathrm{w}$ tym artykule. Lipsjusz wypowiada się tu jednak bardzo oględnie, inaczej niż Lactantius Divinae institutiones III 18: PL 6, kol. 406-409; Hieronymus Epistolae 39, 3: PL 22, kol. 468; Augustinus De civitate Dei I 23-24; XIX 4: PL 41, kol. 36-37, 630; por. też: R.J. Goar, The Legend of Cato Uticensis..., s. 79-100.

„Et robur [tj. Catonis - I.S.] etiam in morte sileo, quod variam interpretationem habere potest, et nostrae religionis scito, culpam", I. Lipsius, Monita et exempla politica, Antwerpen: Ioannes Moretus, 1605, s. 54.

24 Zob. Index horum librorum..., s. 19. 
ponadprzeciętną prawość (probitas) przypisując Porcjuszowi Starszemu, niezłomność (constantia) zaś jego prawnukowi ${ }^{25}$. W tej sytuacji kwestię identyfikacji należałoby zawiesić - o ile nie udałoby się ustalić, śladem jakich lektur poety mogą być twierdzenia, które wypowiada jego Katon.

Pierwszych wskazówek dostarczy ponownie Piotr Urbański, który słowa trzeciej strofy - „Rex aut caesar erit, cui Deus arbitra/ Seu quid sustulerit, seu dederit manu,/ Nulla parte sui maior abiverit,/ Nulla parte sui minor” [„Królem czy cezarem będzie ten, kto nie zyska niczego i nie straci, kiedy Bóg wedle swego uznania da mu coś albo coś odbierze"] (Lyr. II 6, 9-12) - odnosi do ustępu Senekańskiego Thyestesa (do w. 348 - „rex est qui posuit metus” [ „królem jest - kto się nie obawia”] - i następnych), łącznie jednak między innymi z wersem ody IV 3, 21 („Rex est, profanos qui domuit metus”), rzeczywiście zbieżnym pod względem frazeologicznym z miejscem tragedii Anneusza. Zestawia je poza tym nie tylko z passusem z Senekańskich listów, w którym mowa o Katonie (Seneca Epistulae 71, 11) ${ }^{\mathbf{2 6}}$, ale także z ustępem O spokoju ducha (tutaj mamy wzmiankę o Juliuszu Kanusie, który w spokoju oczekiwał na własną egzekucję, grając w szachy - Seneca De tranquillitate 14, 4-10), a ponadto z pewną liczbą miejsc, w których pojawia się ogólny imperatyw władania samym sobą (Seneca Epistulae 2, 1; 7, 8; 23, 6; 25, 7; 27, 3; 31, 3; 33, 4; 55, $4-5 ; 60,4 ; 62,1 ; 75,18 ; 76,11)^{\mathbf{2 7}}$.

Jeśli chodzi o trzecią strofę Cato Politicus, można jednak dostrzec mniej ogólnej natury powinowactwo zawartego w niej konceptu z myślą Seneki wyłożoną w liście 74. Anneusz dowodzi tu, że właściwie pojętym dobrem, którego nie można utracić, obdarza ratio; dobro to jest tożsame z tym, co godziwe (honestum). Pozostałe rzekome dobra należą do nas tylko formalnie, mają charakter zewnętrzny i należy je uznać za tymczasowo sobie powierzone; ktokolwiek rzeczy te (potomstwo, zaszczyty, majątek, zdrowie czy życie) utożsamia z dobrem, przestaje być panem samego siebie (Seneca Epistulae 74, 16-17 i 74, 1-4). Myśl tę zestawmy z ustępem innego listu, w którym Seneka, wspominając Attalosa, swojego nauczyciela wpajającego w uczniów zamiłowanie do cnoty i obojętność wobec przyjemności zmysłowych, podaje, że Attalos uważał się za króla (rex) (Seneca Epistulae 108, 12-14).

Korespondencję - w zakresie zarówno treści, jak i sentencjonalnej formy - dostrzeżemy również między innym ustępem tego samego listu 108 a pierwszą strofą ody. Zawarta w dwóch pierwszych wersach konstatacja, że daremne jest gromadzenie bogactw, skoro posiadacz z nich nie korzysta, w kolejnych wzmocniona została aforystycznym spostrzeżeniem wydobywającym absurd ulegania chciwości: „Auri stulta fames ${ }^{\mathbf{2 8}}$ ipsa sibi negat,/ Quidquid omnibus abstulit” [„Bezmyślna żądza złota

25 I. Lipsius, Monita et exempla..., s. 48, 52-54.

26 Zob. s. 5 w tym artykule.

27 P. Urbański, Między ignacjanizmem a neostoicyzmem, s. 106-108.

28 Por. także: „iuvenem, quem modo barbara/ Auri corripuit fames” (Lyr. I 9, 7-8) i „cupido belli crevit atque auri fames” (Pseudo-Seneca Octavia 425) oraz „quid non mortalia pectora cogis,/ auri sacra fames!" (Vergilius Aeneis III, 56-57). 
odmawia samej sobie wszystkiego, co odebrała innym"] (Lyr. II 6, 3-4). U Anneusza absurd ten wyraża sentencjonalny dwuwiersz zaczerpnięty od poety i aktora mimicznego Publiliusza Syrusa (Seneca Epistulae 108, 9): „Ubóstwu brakuje wiele, chciwości brak wszystkiego./ Chciwy każdego traktuje źle, a najgorzej - siebie"29. Tę samą myśl Seneka wyraził w formie bardziej dyskursywnej w liście 115, w którym dowodzi, że dążący do zaszczytów czy bogactw nigdy nie zadowalają się swym stanem posiadania i choć coraz bogaci, nieustannie są cierpiącymi nędzarzami (Seneca Epistulae 115, 16-17) ${ }^{30}$. Krócej filozof formułuje tę myśl w przywołanym tu już liście 74, mówiąc o „nędzarzach opływających w bogactwa” („in divitiis inopes”, Seneca Epistulae 74, 4).

Anneusz oprócz zachęty, by jedyne dobro widzieć w umyśle (animus) (Seneca Epistulae 74,16$)^{31}$, wyraża tam również przekonanie, że tylko ratio zapewnia dobra wiecznotrwałe („solida ac sempiterna”, Seneca Epistulae 74, 16), a cnota (virtus) jest źródłem wszystkich dóbr, nieustającym i niedopuszczającym braku; filozof ilustruje tę myśl metaforą potoku, który wypływa z niewyczerpanego źródła (Seneca Epistulae 74, 25). Gdy weźmiemy pod uwagę, że animus, ratio i virtus występują tu jako terminy bliskoznaczne, oraz uzupełnimy tę wypowiedź twierdzeniem o łatwości zachowywania $v_{\text {irtus }}{ }^{32}$, uzasadnione będzie uznać ją za zbieżną z treścią drugiej strofy omawianej ody, z jej pochwałą bogactw umysłowych (animus, consilium), łatwo dostępnych, nieskończenie wzrastających i których pomniejszenia nie trzeba się obawiać (Lyr. II 6, 5-8).

W czwartej i piątej strofie wiersza (Lyr. II 6, 13-20) dostrzeżemy alegorię pokrewną metaforycznemu wyobrażeniu, które stanowi medium warstwy refleksyjnej w odzie IV 28, będącej poszerzoną parafrazą fraszki (I 101) Jana Kochanowskiego Do Mądrości Bożej ${ }^{33}$. Alegorie te różnią się jednak - zwłaszcza ze względu na charakter instancji przeciwstawionej ludzkiej ciżbie. W odzie IV 28 instancja owa nosi miano „Mądrości Boskiej” lub „myśli” („Divina Sapientia”, „mens”, Lyr. IV 28, 1 oraz nagłówek), która rządząc przemianami zachodzącymi w świecie ${ }^{34}$, może skądinąd wzbudzać podziw dla swych wyroków ${ }^{35}$; podmiot mówiący chciałby śmiać się razem $\mathrm{z}$ nią $\mathrm{z}$ chciwego, walczącego tłumu ${ }^{36}$. W utworze pojawia się też kategoria „losu” (sors), nietożsamego jednak, jak się wydaje, $\mathrm{z}$ „Mądrością Bożą”, do której podmiot zwraca się w drugiej osobie ${ }^{37}$. Raczej należałoby uznać, że mamy tu (podwójną) hypallage, a zdanie „sors avidis quod secat ensibus” [„,co los rozsiecze chciwymi mieczami”]

29

30

\footnotetext{
„Desunt inopiae multa, avaritiae omnia./ In nullum avarus bonus est, in se pessimus”.

Por. też: Seneca Epistulae 115, 16: „quam misera [tj. avaritia - I.S.] desideratis, quam misera partis est!” [„Jakże dręczy ją [tj. chciwość] brak, jak dręczy posiadanie!].

Zob. też s. $7 \mathrm{w}$ tym artykule.

Zob. zwłaszcza Seneca Epistulae 80, 2-3, por. też np. Seneca Epistulae 115, 3-5.

Zob. J. Kochanowski, Fraszki, oprac. J. Pelc, Wrocław 1991, s. 46-47.

Por. „stabili fata regis vice”, Lyr. IV 28, 1.

Por. „Ut nos pulchra tui seria consilii [...] delectent”, Lyr. IV 28, 2-4.

Por. „Secum avidi dum/ Pugnant, tecum ego rideam”, Lyr. IV 28, 15-16.

Zob. Lyr. IV 28, 1-8, 16.
} 
(Lyr. IV 28, 13) - rozumieć jak „sorte avidorum quod secant enses” [„co [ślepym] trafem rozsieką miecze chciwców”] ${ }^{38}$. W odzie II 6 (13-20) to „los” (sors) rozrzuca datki wśród pospólstwa i drwi z próżnych zabiegów i utarczek, których są przyczyną; bohater pozostawia je głupcom. Chciałby się śmiać, lecz nie wespół z „losem”, a pośrodku tłumu, odstąpiwszy zastępcy tymczasową rolę na scenie (Lyr. II 6, 29-36) ${ }^{39}$ chodzi tu więc o odmienne koncepty mimo pewnego podobieństwa alegorycznych wyobrażeń. Koncept bardziej odpowiadający występującemu w strofach czwartej i piątej ody II 6 znajdujemy natomiast u Seneki (Epistulae 74, 7-9) ${ }^{\mathbf{4 0}}$ :

Hanc enim imaginem animo tuo propone, ludos facere fortunam et in hunc mortalium coetum honores, divitias, gratiam excutere, quorum alia inter diripientium manus scissa sunt, alia infida societate divisa, alia magno detrimento eorum in quos devenerant prensa. [...] Secedamus itaque ab istis ludis et demus raptoribus locum; illi spectent bona ista pendentia et ipsi magis pendeant.

[Wyobraź sobie, że Fortuna urządza igrzyska i między zgromadzonych śmiertelników rozrzuca godności, bogactwa, łaski; jedne rozszarpią, wydzierając je sobie z rąk, drugimi podzielą się z przewrotnymi wspólnikami, inne pochwycą na swoją własną szkodę. [...] Toteż uchodźmy z tych igrzysk - ustąpmy miejsca zbójom; niech o te zależne od losu dobra zabiegają sami i sami niech bardziej się uzależniają].

38 Por. „avidi dum/ Pugnant”, Lyr. IV 28, 15-16.

39 Zob. s. $11 \mathrm{w}$ tym artykule.

40 Warto w tym miejscu postawić pytanie, czy ten sam ustęp Senekańskiego listu 74 nie mógł być jednocześnie jednym z miejsc inspiracji Kochanowskiego - w połączeniu np. z obszernym passusem O opatrzności (Seneca De providentia 2, 8-12). Mowa tu o bogu lub bogach, którzy zażywają rozrywki na podobieństwo ludzi, oglądając igrzyska - w tym przypadku chodzi jednak o zmagania cnotliwych męźów z losem. Wyobrażenie to ma wymiar alegoryczny, kategorię „bogowie” należałoby bowiem odnieść do filozoficznego pojęcia bóstwa jako pierwszej zasady czy natury (zob. np. Seneca De providentia 5,8 ). Na inne similia wskazuje Janusz Pelc (Jan Kochanowski. Szczyt renesansu w literaturze polskiej, Warszawa 1980, s. 290-291). O ile jednak można się zgodzić z badaczem co do ich doboru w przypadku pozostałych wyobrażeń świata jako teatru u Kochanowskiego, o tyle alegoria w wersach 5-10 fraszki I $1010 \dot{z} y$ wocie ludzkim wydaje się korespondować przede wszystkim ze wskazanym passusem z listu 74 Seneki. Na temat alegorii życia ludzkiego jako sztuki u autorów antycznych i wybranych pisarzy późniejszych aż po XVII wiek zob. też: L.G. Christian, Theatrum Mundi: The History of an Idea, New York-London 1987, s. 1-205; katalog Senekańskich nawiązań do toposu świata jako teatru w: M. Armisen-Marchetti, Sapientiae facies. Étude sur les images de Sénèque, Paris 1989, s. 166-167. Dodajmy, że u samego Seneki kategoria losu (fatum, fortuna) niekiedy występuje w znaczeniu przypadku czy wrogiej siły, której można i należy się przeciwstawić, niekiedy zaś zbliża się znaczeniowo do „boskiej ratio” (divina mens) (zob. więcej np. T. Sapota, I. Słomak, Komentarz, w: L. Annaeus Seneca, Edyp. Oedipus, wstęp, edycja, przekład i komentarz T. Sapota, I. Słomak, Katowice 2017, s. 147, oraz T. Sapota, I. Słomak, „Kobiety fenickie” Lucjusza Anneusza Seneki. Opracowanie monograficzne, Katowice 2019, s. 112, 120). Stąd w utworach inspirowanych różnymi tekstami Seneki możemy oczekiwać zamiany obu znaczeń lub też nieostrości terminów odnoszących się do „losu”. W odzie IV 28 Sarbiewskiego daje się poza tym nie tylko dostrzec inspiracje wspomnianą fraszką Kochanowskiego, ale także wskazać niezależne od wymienionych korespondencje z myślą Senekańską, na co zwraca uwagę Elwira Buszewicz (Maciej Kazimierz Sarbiewski - „Ody” refleksyjne..., s. 128-130). Por. też: Seneca Epistulae 8, 3-4. 
W strofach szóstej i siódmej ody Sarbiewskiego bohater deklaruje gotowość do przyjęcia uczciwie zdobytych godności, z zastrzeżeniem, że potraktuje je jako depozyt („utar [...]/ Tamquam deposito”), który bez żalu odda swojemu następcy (Lyr. II 6, 21-28). Myśl ta - ogólnie, choć nie w szczegółach obrazowania - jest zbieżna z wykładem Seneki w dalszej części listu 74 (17-18), zwłaszcza zaś z treścią zdania (Seneca Epistulae 74, 18): „Niechże to staje się nasze, lecz do nas nie przywiera, byśmy nie wpadli w rozpacz, kiedy zostanie odebrane. Nie chlubmy się tym, lecz tego używajmy - wstrzemięźliwie, jak rzeczy tymczasowo oddanych nam w depozyt"41.

Zalecenie takie pojawia się również w Anneuszowym Pocieszeniu do Marcji, w połączeniu z kolejną obrazową metaforą. Seneka porównuje tu bogactwa, godności oraz inne dobra życiowe do wypożyczonych sprzętów, którymi przyozdabia się scenę i które następnie wrócą do swoich właścicieli, korzystający zaś z nich (w domyśle: aktorzy) użytkują je krótko (Seneca Consolatio ad Marciam 10, 1-2):

Conlaticiis et ad dominos redituris instrumentis scaena adornatur; alia ex his primo die, alia secundo referentur, pauca usque ad finem perseverabunt. Itaque non est quod nos suspiciamus tamquam inter nostra positi: mutua accepimus. [...] nos oportet in promptu habere quae in incertum diem data sunt et appellatos sine querella reddere.

[Przyozdabia się scenę sprzętem pożyczonym z różnych miejsc, który musi wrócić do swoich właścicieli; niektóre z tych rzeczy zwraca się pierwszego dnia, niektóre w dniu następnym, a bardzo mało zostaje aż do końca. Toteż nie jest to nic, co moglibyśmy podziwiać niby panowie pośród swoich włości: to rzeczy pożyczone. [...] musimy mieć pod ręką te dane nam nie wiadomo na jak długo rzeczy i kiedy trzeba, oddać je bez skargi].

Anneusz niejednokrotnie odwołuje się do podobnego obrazowania, mówiąc o rolach, w które ludzie wcielają się w życiu na podobieństwo aktorów scenicznych. Wyposaża się ich w koturny, berła i płaszcze, lecz zwracają je po odegraniu przed widzami swojej partii. Taki obraz pojawia się na przykład w ustępie listu $76(30-31)^{\mathbf{4 2}}$, w którym Seneka podejmuje też obszernie temat związku między dobrem a umysłem:

Hoc ergo unum bonum est, quod non tantum perfectus animus sed generosus quoque et indolis bonae sentit: cetera levia sunt, mutabilia. [...] Nemo ex istis quos purpuratos vides felix est, non magis quam ex illis quibus sceptrum et chlamydem in scaena fabulae adsignant: cum praesente populo lati incesserunt et cothurnati, simul exierunt, excalceantur et ad staturam suam redeunt.

[Jedynym dobrem jest rzecz utożsamiana z dobrem nie tylko przez umysł doskonały, ale także przez człowieka szlachetnego i dobrego charakteru - reszta to rzeczy błahe i ulotne.

41 „Omnia ista nobis accedant, non haereant, ut si abducentur, sine ulla nostri laceratione discedant. Utamur illis, non gloriemur, et utamur parce tamquam depositis apud nos et abituris".

42 Podobnie Seneca Epistulae 80, 7-8; por. (metafora życia jako sztuki) Seneca Epistulae 77, 20. 
[...] Nikt spośród ludzi, których widzisz w purpurze, nie jest szczęśliwy - nie więcej szczęścia ma niż ci, którym ze względu na treść sztuki przysługuje na scenie berło i chlamida; jeśli ukazują się widzom okazali i na koturnach, to muszą też zejść ze sceny, zzuć obuwie, być znów tymi, kim są].

Przywołane miejsca uzupełnijmy o inny passus - Anneusz zachęca w nim do przyjęcia postawy niezaangażowanego widza, który podczas zgromadzenia bawi się, śledząc zabiegi kandydatów na urzędy, i z tą samą beztroską obserwuje cudze wysiłki służące zdobyciu innych dóbr życiowych. Dzięki swojemu dystansowi uniezależnia się od losu (Seneca Epistulae 118, 3-4):

Quam putas esse iucundum tribubus vocatis, cum candidati in templis suis pendeant et alius nummos pronuntiet, alius per sequestrem agat, alius eorum manus osculis conterat quibus designatus contingendam manum negaturus est [...], stare otiosum et spectare illas nundinas nec ementem quicquam nec vendentem. Quanto hic maiore gaudio fruitur qui non praetoria aut consularia comitia securus intuetur, sed magna illa in quibus alii honores anniversarios petunt, alii perpetuas potestates, alii bellorum eventus prosperos triumphosque, alii divitias, alii matrimonia ac liberos, alii salutem suam suorumque! Quanti animi res est solum nihil petere, nulli supplicare, et dicere, 'nihil mihi tecum, fortuna; non facio mei tibi copiam. Scio apud te Catones repelli, Vatinios fieri. Nihil rogo'.

[Myślisz, że gdy we wszystkich dzielnicach obwieści się wybory, gdy kandydaci trwożą się na swych podwyższeniach i jeden obiecuje pieniądze, drugi działa przez pośrednika, trzeci całuje ręce tych samych ludzi, którym, ogłoszony już zwycięzcą, odmówi uściśnięcia dłoni [...] - nie jest przyjemnie stać sobie beztrosko i przyglądać się owym targom, samemu nic nie kupując i nie sprzedając? O ile lepszej rozrywki zażywa ktoś, kto spokojnie przygląda się już nie owym zgromadzeniom, podczas których wybiera się pretora czy konsula, ale tym powszechnym, na których jedni zabiegają o roczny urząd, drudzy o stałą władzę, jedni o pomyślny wynik wojen i triumfy, drudzy o bogactwa, jedni o małżeństwa i potomstwo, drudzy o bezpieczeństwo własne i bliskich! Jakiej wielkości umysłu trzeba, żeby samemu o nic się nie ubiegać, nikogo nie błagać i mówić: „nic mi do ciebie, losie, nie daję ci nade mną władzy. Wiem, że u ciebie przegrywają Katonowie, a wybiera się Watyniuszów. Nie proszę o nic"].

Tak zestawione alegorie - zaszczytnej godności jako roli aktora tragediowego, atrybutów władzy jako rekwizytów przechodzących z rąk do rąk oraz mędrca jako zdystansowanego widza - odnajdziemy w dwóch ostatnich strofach ody Sarbiewskiego, w których bohater zapewnia, że po odegraniu sztuki zdejmie kostium, purpurę lub togę, i z przyjemnością zajmie miejsce w tłumie, by przypatrywać się tragedii z udziałem swoich zastępców (Lyr. II 6, 29-36).

Senekańskie inspiracje Sarbiewskiego jako autora Cato Politicus wydają się bardzo prawdopodobne, przy uwzględnieniu jednak tylko przywołanych dotychczas similiów identyfikacja bohatera ody w dalszym ciągu nastręczałaby trudności. 
Miejsca te zawierają refleksję ogólną i nie dotyczą bezpośrednio Katona; tylko w ostatnim z nich pojawia się jego nazwisko (z kontekstu wynika jednocześnie, że chodzi o Katona Utyckiego ${ }^{\mathbf{4 3}}$ ), użyte jednak antonomastycznie w znaczeniu 'prawi ludzie', Seneka zaś nie stwierdza wprost, że wyraża pogląd podzielany przez Porcjusza Młodszego. W związku z tym można by zapytać, dlaczego w nagłówku utworu tak intensywnie eksploatującego myśl pisarza z Korduby nie znalazło się raczej miano samego Seneki. Odpowiadając, warto odwołać się ponownie do listów Anneusza, który do Katona - przede wszystkim Katona Utyckiego - odnosi się z wyjątkową rewerencją. Nie tylko wielokrotnie sięga do jego vita, aby zilustrować rozważania i rady o charakterze ogólnym, ale i zaleca swojemu adresatowi, by miał stale przed oczyma wzór do naśladowania czy też osobistego stróża i sędziego - wzorem takim może być między innymi Katon (Seneca Epistulae 25, 5-6) ${ }^{\mathbf{4 4}}$ :

Prodest sine dubio custodem sibi inposuisse et habere quem respicias, quem iteresse cogitationibus tuis iudices. Hoc quidem longe magnificentius est, sic vivere tamquam sub alicuius boni viri ac semper praesentis oculis [...]. Cum iam profeceris tantum ut sit tibi etiam tui reverentia, licebit dimittas paedagogum: interim aliquorum te auctoritate custodi - aut Cato ille sit aut Scipio aut Laelius aut alius cuius interventu perditi quoque homines vitia supprimerent $[\ldots]$.

[Bez wątpienia warto obrać sobie stróża i mieć na kogo się oglądać, mieć kogoś, o kim byś sądził, że czyta w twoich myślach. Wszak dalece wspanialej jest żyć jakby na oczach jakiegoś prawego, zawsze obecnego przy tobie człowieka [...]. Gdy już dojdziesz do tego, że będziesz czuł respekt i przed samym sobą, możesz oddalić wychowawcę, a tymczasem miej na względzie autorytet innych - albo Katona, albo Scypiona, albo Leliusza, albo kogoś innego, w czyjej obecności miarkowaliby się nawet całkiem zdeprawowani ludzie].

Prezentację charakteru Katona za pośrednictwem poetyckich parafraz myśli Senekańskiej Sarbiewski mógł uznać za celną i usprawiedliwioną właśnie ze względu na ową atencję, z jaką Anneusz odnosi się do jednej z najwybitniejszych postaci rzymskiej sceny politycznej końca republiki. Zastąpienie nazwiska Seneki imieniem jego autorytetu moralnego może też służyć odjęciu myśli tego pierwszego piętna określonej schola - zalecenia słynnego stoickiego filozofa prezentowane są w ten sposób jako credo człowieka będącego uosobieniem prawości, podziwianego przez współczesnych i potomnych bez względu na ich stosunek do szkoły stoickiej (jej wyznawcą był wszak również Katon ${ }^{45}$ ). Pozbawiona zaś etykietki nauki stoickiej myśl

43 Publiusz Watyniusz był kontrkandydatem Katona Utyckiego podczas wyborów na pretora na rok 55 p.n.e., w których Porcjusz przegrał. Watyniusz - według relacji Plutarcha (Cato Minor 41-42) został wybrany w wyniku machinacji Cezara, Pompejusza i Krassusa, którzy doprowadzili do unieważnienia pierwszych wyborów i przekupili wyborców.

44 Por. też: Seneca Epistulae 11, 9-10.

45 Por. przyp. $9 \mathrm{w}$ tym artykule. 
ta pozwalałaby łatwiej się przyswoić - jako należąca do szeroko rozumianego dziedzictwa intelektualnego, z którego zasobów czerpie się nie ze względu na wierność danej szkole, lecz w celu wzbogacenia środków wyrazu poglądów już zaakceptowanych (w tym przypadku zgodnych z kanonem wartości chrześcijańskich). Zachętę do takiego niezobowiązującego anektowania Sarbiewski mógłby znaleźć w samych listach Anneusza, który wielokrotnie podkreśla, że czerpie od przedstawicieli innych szkół - ich dorobek traktuje jako dobro wspólne, o ile może go zaakceptować w ramach przyjętego już paradygmatu wartości (Seneca Epistulae 12, 11) ${ }^{\mathbf{4 6}}$ :

\footnotetext{
'Epicurus' inquis 'dixit: quid tibi cum alieno?' Quod verum est meum est; perseverabo Epicurum tibi ingerere, ut isti qui in verba iurant nec quid dicatur aestimant, sed a quo, sciant quae optima sunt esse communia.

[„To słowa Epikura - powiadasz - co masz z nim wspólnego?” Co jest prawdą, jest moje; będę dalej przytaczał ci Epikura, żeby zaprzysięgli wyznawcy cudzych poglądów, dla których nie jest ważna treść, lecz autor wypowiedzi, pojęli, że to, co doskonałe, stanowi własność powszechną].
}

Trzeba wreszcie podkreślić, że Sarbiewski zdaje się równie intensywnie eksploatować Senekańską myśl także między innymi w odach sąsiadujących z Cato Politicus. Celowe będzie w tym miejscu zestawienie miejsc dwóch wybranych liryków oraz ustępów prozy i poezji Seneki - przede wszystkim aby podkreślić, że omówiona oda II 6, jeśli chodzi o jej inspiracje, nie może być uznana za wyjątek i trzeba w niej widzieć utwór reprezentatywny dla całego cyklu wierszy Sarbiewskiego. Zestawienie to pokazuje skądinąd, jak ważną rolę w Anneuszowej nauce odgrywa przykład Katona, i czyni bardziej zrozumiałą fascynację republikańskim herosem ze strony czytelnika wykładów rzymskiego filozofa. Dodatkowo warto wskazać, że oda II 5 analizowana w kontekście lektury Seneki ujawnia swój charakter tradycyjnej (stoickiej) filozoficznej medytacji ${ }^{47}$ - ćwiczenia w ujęciu Sarbiewskiego niemającego zapewne służyć specjalnemu dowartościowaniu kultury pogańskiej, z której się wywodziło, ale uwydatnić swój uniwersalny wymiar. Założyli go wszak twórcy jezuickiej ustawy szkolnej, którzy przewidzieli, że wykształcenie na poziomie średnim w kolegiach oprze się zasadniczo na znajomości kanonu niechrześcijańskiej literatury antycznej. Oda II 7 w tym samym kontekście jawi się zaś jako poetycka wariacja na temat określony przez ramy stoickiego pocieszenia.

W pierwszej oraz w jednej z końcowych strof utworu E rebus humanis excessus (Lyr. II 5) można doszukać się konceptu powielonego za Senekańskim Thyestesem,

\footnotetext{
46 Por. Seneca Epistulae 2, 5; 8, 8; 13, 17; 14, 17-18;16, 7; 21, 9; 33, 1-11 i in. Na tego rodzaju inspirację Sarbiewskiego wskazała już wcześniej Elwira Buszewicz (Sarmacki Horacy i jego liryka..., s. 177).

47 Por. uwagi w przyp. $78 \mathrm{w}$ tym artykule.
} 
dramatem parafrazowanym przez Sarbiewskiego wielokrotnie ${ }^{48}$. Ze względu na kontekstowe znaczenie fraz „tollite praepetem,/ Nubesque ventique” [„unieście w przestworza, chmury i wiatry”] (Lyr. II 5, 1-2) oraz „Tollite praepetem/ Festina vatem, tollite, nubila” [„prędkie obłoki, w przestworza unieście wieszcza”] ( Lyr. II 5, 73-74), wyrażających zarówno chęć ucieczki, jak i pośpiechu w drodze do celu, można uznać je za erudycyjne nawiązanie nie tylko do słów Posłańca $\mathrm{w}$ Thyestesie (pragnie on pozostawić za sobą dręczące go wspomnienie), ale i do słów Jokasty z Kobiet fenickich (królowa spieszy tu na pole walki) ${ }^{49}$. Także dwuwers, w którym mowa o coraz większym wyrafinowaniu zła - „Rarum sub exemplo superbit,/ Nec sceleris scelus instar omne est” [„Wyszukane [zło] pyszni się, służąc wzorem, i pospolitą nie jest każda zbrodnia"] (Lyr. II 5, 39-40) - wydaje się finezyjną parafrazą słów Furii z prologu Thyestesa ${ }^{50}$. Nawiązania te spełniają niewielką funkcję w organizacji semantycznej utworu, choć uczestnika kultury literackiej, którą reprezentował Sarbiewski, mogły ogólnie nakierowywać na przedmiot emulacji autora ody. Sytuacja podmiotu lirycznego - przyjmuje szeroką perspektywę, która pozwala mu ogarnąć świadomością przemiany następujące w świecie (podczas pokoju i w czasie wojny, wskutek trzęsienia ziemi i w wyniku powodzi), a na ich tle niepewność czy daremność ludzkich przedsięwzięć (Lyr. II 5, 10-70), następnie zaś zestawić ów niepewny los z błogim doświadczeniem nieśmiertelności (Lyr. II 5, 70-85) - koresponduje jednak przede wszystkim z sytuacją nakreśloną przez Senekę w liście 71. Anneusz wprost przywołuje tutaj przykład Katona (Utyckiego), który miał z pogodą reagować na przemiany zachodzące w państwie ${ }^{51}$ właśnie dzięki zdolności do przyjęcia podobnej perspektywy (Seneca Epistulae 71, 15) ${ }^{52}$ :

Itaque ut M. Cato, cum aevum animo percurrerit [tj. mens nostra - I.S.], dicet, 'omne humanum genus, quodque est quodque erit, morte damnatum est; omnes quae usquam rerum potiuntur urbes quaeque alienorum imperiorum magna sunt decora, ubi fuerint aliquando quaeretur et vario exitii genere tollentur: alias destruent bella, alias desidia paxque ad inertiam versa consumet et magnis opibus exitiosa res, luxus. Omnes hos fertiles campos repentini maris inundatio abscondet aut in subitam cavernam considentis soli lapsus abducet. Quid est ergo quare indigner aut doleam, si exiguo momento

48 Niektóre similia wskazuje Piotr Urbański (Między ignacjanizmem a neostoicyzmem, s. 101, 104, 106, $110)$.

49 Por. „Quis me per auras turbo praecipitem vehet/ atraque nube involvet” [„Gdyby tak jakiś wicher czarną chmurą mnie omotał i w przestworza poniósł”] (Seneca Thyestes 623-624) oraz „Quis me procellae turbine insano vehens/ volucer per auras ventus aetherias aget?” [„Gdyby tak jakiś wiatr mnie pognał lotny w szalonym wirze przez rozstaje nieba!"] (Seneca Phoenissae 420-421). „semper oriatur novum/ nec unum in uno" [„niech stale [zło - I.S.] się odmienia i rozrasta” - Seneca Thyestes 30-31.

51 Zob. Seneca Epistulae 71, 11-12; por. też s. 5 w tym artykule.

52 Por. też: Seneca Epistulae 71, 13-14. 
publica fata praecedo?' Magnus animus deo pareat et quidquid lex universi iubet sine cunctatione patiatur: aut in meliorem emittitur vitam lucidius tranquilliusque inter divina mansurus aut $[\ldots]$.

[Toteż gdy, jak Marek Katon, przebiegniemy myślą wieki, powiemy sobie: „Cały rodzaj ludzki, który istnieje i będzie istnieć, skazany jest na śmierć. O wszystkie potężne miasta i o grody będące chlubą innych potęg będą się kiedyś ludzie pytać, gdzie się znajdowały, a zginą one w rozmaity sposób. Jedne zniszczą wojny, drugie strawi próżniactwo i pokój winny ich uwiądu, i zgubny dla bogactwa zbytek. Wszystkie te urodzajne pola znienacka pochłonie morze albo zapadną się niespodziewanie, gdy się obsunie grunt. Dlaczego zatem miałbym oburzać się i ubolewać nad tym, że wyprzedzę nieco kres, który czeka wszystko? Człowiek wielkiego ducha ma być posłuszny bogu i bez ociągania się znieść wszystko, co nakazuje prawo powszechne: albo przeniesie się do lepszego życia, by w większym blasku i spokoju bytować w świecie boskim, albo [...]].

Podobny koncept znajdujemy w Pocieszeniu do Marcji. Tym razem Seneka nie proponuje przeprowadzenia doświadczenia imaginacyjnego wzorowanego na doświadczeniu mistrza (tj. Katona), ale ćwiczenia pod dyktando nauki mistrza - wiarygodnego w swoim zdystansowaniu się wobec świata, bo w roli tej występuje zmarły ojciec formalnej adresatki konsolacji. Nieco większa niż w poprzednim przykładzie zbieżność obrazowania Sarbiewskiego z obrazowaniem Seneki wynika tu ze wskazania wprost na perspektywę $\mathrm{z}$ wysokości nieba ${ }^{\mathbf{5 3}}$ (Seneca Consolatio ad Marciam 26, 1): „Wyobraź sobie zatem, Marcjo, że z owego niebieskiego zamku przemawia twój ojciec [...], z polotem tym większym, że bardziej z wysoka"54. Ojciec Marcji, jak naśladowca Katona z listu 71, dzięki szerokiemu horyzontowi poznawczemu, obejmującemu stulecia, uświadamia sobie przemijalność zarówno ludzi oraz cywilizacji, jak i tworów samej natury; przeciwstawia także swój obecny spokój wrzawie towarzyszącej sprawom ziemskim (Seneca Consolatio ad Marciam 26, 3-6). Dodajmy, że chociaż Seneka unika w tym miejscu wyrażeń pozwalających bardziej bezpośrednio skojarzyć sytuację mędrca śledzącego z dystansu sprawy ziemskie z sytuacją widza teatralnego - podczas gdy wprowadza je Sarbiewski (Lyr. II 5, 66-70) - pierwsza z tych sytuacji może implikować drugą, zwłaszcza jeśli pamiętamy o pojawiających się gdzie indziej u Seneki ${ }^{55}$ metaforach życia ludzkiego jako sztuki, dóbr życiowych

$53 \quad$ Niemniej można uznać, że szeroka perspektywa, o której mowa w ustępie Senekańskiego listu 71 (15), jest tożsama z perspektywą „z wysoka”. Por. z przykładem, w którym również jest mowa o ćwiczeniu imaginacyjnym: „ubi stabilita mens scit nihil interesse inter diem et saeculum, quidquid deinceps dierum rerumque venturum est ex alto prospicit et cum multo risu seriem temporum cogitat” ["gdy umysł się zahartuje i wie, że nie ma żadnej różnicy między dniem i wiekiem, na wszystkie przyszłe dni i sprawy patrzy z wysoka i bardzo bawi go dumanie nad biegiem czasu"], Seneca Epistulae 101, 9.

54 „Puta itaque ex illa arce caelesti patrem tuum, Marcia, [...] ingenio [...] tanto elatiore quanto est ipse sublimior dicere".

55 Por. s. 10-11 w tym artykule. 
jako rekwizytów scenicznych oraz gawiedzi spierającej się w teatrze Fortuny o fałszywe dobra.

Z miejsc korespondujących ze sobą ze względu na obrazowanie szczegółowe należałoby zestawić passus (Lyr. II 5, 77-83), w którym doświadczenie oddalania się od spraw świata oddane zostało za pomocą opisu malejących państw i ludów, a następnie samego globu ziemskiego, zredukowanego do rozmiarów punktu, oraz inny ustęp tego samego Pocieszenia do Marcji. Anneusz proponuje tu kolejne ćwiczenie wyobraźni, którego celem jest osiągnięcie dystansu wobec kondycji śmiertelnika (Seneca Consolatio ad Marciam 21, 2) ${ }^{\mathbf{5 6}}$ :

Omnia humana brevia et caduca sunt et infiniti temporis nullam partem occupantia. Terram hanc cum urbibus populisque et fluminibus et ambitu maris puncti loco ponimus ad universa referentes: minorem portionem aetas nostra quam puncti habet, si omni tempori comparetur, cuius maior est mensura quam mundi, utpote cum ille se intra huius spatium totiens remetiatur.

[Wszystko, co ludzkie, jest krótkie i nietrwałe i niczym jest w stosunku do wieczności. Ziemię tę razem z jej miastami, ludami, rzekami i otaczającym ją morzem uznamy za punkt, porównując ją z wszechświatem; długość zaś naszego życia będzie mniejsza niż punkt, gdy zestawimy ją z wiecznością, której miara przekracza miarę świata - wszak pierwsza jest mnogą wielokrotnością drugiej].

Przeciwstawienie dwóch planów - ludzkiego, niesłusznie podziwianego („Humana mirer?”, Lyr. II 5, 73), oraz niebieskiego, pogodnej siedziby rozświetlonej słońcem („serenas/ Sole domos [...]/ Qua solis et lunae labores/ Caeruleo vehit aethra campo", Lyr. II 5, 71-76) - znajdujemy także między innymi w liście 102, w którym Seneka kontrastuje doczesne przebywanie w ciele $\mathrm{z}$ uczestnictwem w świecie boskim, przenikniętym blaskiem (Seneca Epistulae 102, 27-28) ${ }^{57}$ : „Nadejdzie dzień, który cię wyrwie, wywiedzie z nory plugawego, cuchnącego brzucha. [...] Wyobraź sobie tę światłość bijącą od tylu naraz gwiazd. Nic nie zmąci pogody [...]"58. W innym

56 Parafrazą incipitu tego ustępu, jak wskazuje Elwira Buszewicz, jest prawdopodobnie podtytuł ody III 12 Sarbiewskiego: Omnia humana caduca incertaque esse, zob. E. Buszewicz, Maciej Kazimierz Sarbiewski - „Ody” refleksyjne..., s. 123-124; eadem, Sarmacki Horacy i jego liryka..., s. 199. Por. także z ustępem O zjawiskach natury (Seneca Naturales quaestiones I praef., 9-11), w którym również znajdujemy porównanie ziemi do punktu. Ustęp ten Sarbiewski przywołuje w O poincie i dowcipie (w: M.K. Sarbiewski, Wykłady poetyki. Praecepta poetica, przeł. i oprac. S. Skimina, Wrocław 1958, s. 24-27), o czym również wspomina Buszewicz (Maciej Kazimierz Sarbiewski - „Ody” refleksyjne..., s. 129-130; Sarmacki Horacy i jego liryka..., s. 207-208) przy okazji omawiania ody IV 28 poety. Zob. też inne porównania czasu życia ludzkiego do punktu: Seneca Epistulae 49, 3 i 77,12 .

57 Por. też: Seneca Epistulae 102, 21-28.

58 „[...] veniet qui te revellat dies et ex contubernio foedi atque olidi ventris educat. [...] Imaginare tecum quantus ille sit fulgor tot sideribus inter se lumen miscentibus. Nulla serenum umbra turbabit [...]”. 
z Senekańskich listów - przy okazji zachęty, aby temu, co wieczne i duchowe, dać pierwszeństwo przed doczesnym i materialnym - znajdujemy kolejne zaproszenie do kontemplacji nieskończoności jeszcze za życia (Seneca Epistulae 58, 27): „Słabi i ulotni stoimy pośród mar: przenieśmy się myślą do wieczności. Podziwiajmy unoszące się w przestworzach idee rzeczy, a pośród nich boga [...]"59. Warto też zwrócić uwagę na powinowactwo alegorii „wyspy pozbawionej portów śmiertelności” („o carentem/ Mortalitatis portubus insulam!”, Lyr. II 5, 84-85), wyobrażającej upragniony cel pielgrzyma Sarbiewskiego, oraz Senekańskiego portu wyspy, błędnie utożsamianego z rafą (Seneca Epistulae 70, 2-3): „[...] wreszcie zaczyna się wyłaniać wspólny całemu rodzajowi ludzkiemu kres. Jakimiż głupcami jesteśmy, utożsamiając go z rafą - to port; niekiedy warto samemu doń zawinąć, unikać go zaś nie należy nigdy"60. Zbliżona do niej alegoria przystani śmierci jako schronienia bezpiecznego i wiecznego pojawia się w Pocieszeniu do Polibiusza (Seneca Consolatio ad Polybium 9, 6-7): „[...] żeglujący po tym morzu, tak burzliwym i wydanym na pastwę wszelkiej pogody, nie ma innego portu, jak tylko śmierć. Toteż nie poskąpisz tego swojemu bratu: spoczywa. Wreszcie wolny, wreszcie bezpieczny, wreszcie jest wieczny"61.

W odzie II 7 uwagę zwróci przede wszystkim korespondencja pomiędzy treścią czterech z pięciu jej strof i częściowo także piątej a ogólną problematyką oraz wybranymi ustępami Senekańskiego listu 91. Anneusz wspomina tu o swoim przyjacielu, Ebutiuszu Liberalisie, przygnębionym wiadomością o pożarze, który w krótkim czasie spustoszył jego rodzinne miasto. Przekonuje swojego adresata, że zdarzenie to nie powinno wywoływać nadmiernych emocji - jako odzwierciedlające ogólną prawidłowość. Z powierzchni ziemi zniknęło już i zniknie w przyszłości wiele słynnych miast oraz innych dzieł ludzkich rąk i samej natury ${ }^{62}$. Klęska, która dotknęła Lyon, nie może zatem prowadzić do uskarżania się na niesprawiedliwość losu (Seneca Epistulae 91, 15): „Na nic takiego nie można się oburzać: przychodzimy na świat, którym rządzą takie prawa"63. Przesłanie podobnej treści zawiera się w upomnieniu skierowanym do tytułowego adresata ody Sarbiewskiego, Publiusza Memmiusza: nie powinien on, poruszony nieszczęściami swoich sąsiadów, zarzucać bóstwom okrucieństwa, pamiętając, że naturalną konsekwencją narodzin jest śmierć (Lyr. II 7, 13-18).

W Anneuszowym liście kilka w szczególności sentencjonalnych uwag wydaje się przedmiotem poetyckiej emulacji ze strony Sarbiewskiego. Zwraca zatem

59 „Inbecilli fluvidique inter vana constitimus: ad illa mittamus animum quae aeterna sunt. Miremur in sublimi volitantes rerum omnium formas deumque inter illa versantem [...]". „[...] novissime incipit ostendi publicus finis generis humani. Scopulum esse illum putamus dementissimi: portus est, aliquando petendus, numquam recusandus [...]”.

$61,[\ldots]$ in hoc tam procelloso et ad omnes tempestates exposito mari navigantibus nullus portus nisi mortis est. Ne itaque invideris fratri tuo: quiescit. Tandem liber, tandem tutus, tandem aeternus est”.

62 Zob. zwłaszcza Seneca Epistulae 91, 4-12.

63 „Nihil horum indignandum est: in eum intravimus mundum in quo his legibus vivitur”. 
uwagę zbieżność strofy pierwszej (Lyr. II 7, 1-4): „Esset humanis aliquod levamen/ Cladibus, si res caderent eadem/ Qua mora surgunt: sed humant repentes/ Alta ruinae” [„Przyniosłoby jakąś ulgę ludziom dotkniętym nieszczęściami, gdyby wszystko upadało $\mathrm{w}$ tempie, $\mathrm{w}$ jakim powstawało, lecz ruina znienacka sprawia pogrzeb gmachom”], oraz passusu (Seneca Epistulae 91, 6): „Przyniosłoby nam jakąś pociechę w niemocy i w naszych przedsięwzięciach, gdyby wszystko ginęło tak nieśpiesznie, jak i powstawało: jednak wzrost postępuje wolno, strata się śpieszy" ${ }^{64}$; strofy drugiej (Lyr. II 7, 5-8): „Nil diu felix stetit: inquieta/ Urbium currunt hominumque fata; Totque vix horis iacuere, surgunt/ Regna quot annis” [„Nic długo nie trwa w miejscu, zaznając pomyślności; biegną losy ludzi i miast, a królestwom ledwie do zgonu wystarcza tyle godzin, przez ile lat wzrastały”], i ustępu (Seneca Epistulae 91, 7): „Żadna rzecz, prywatna czy publiczna, nie trwa niezachwianie; losy, zarówno ludzi, jak i miast, toczą się" ${ }^{\text {" } 5}$, a także (Seneca Epistulae 91, 6): „Cokolwiek wznoszono długo wśród wielkich trudów i zaznając wielkiej łaskawości bogów, to w gruzy obróci jeden dzień” ${ }^{66}$; wreszcie strofy trzeciej (Lyr. II 7, 9-12): „Casibus longum dedit ille tempus,/ Qui diem regnis satis eruendis/ Dixit: elato populos habent mo-/ menta sub ictu” [„Nie docenił pędu nieszczęść ktoś, kto uznał, że królestwom dzień wystarczy do zagłady; dość momentu, by na ludy spadł wymierzony cios”], oraz zdania (Seneca Epistulae 91, 6): „Nie docenił tempa mknących klęsk, kto uznał, że im wystarczy dzień; państwom do zguby dość jest godziny i momentu"67.

Warianty aforyzmu z ostatniej strofy (Lyr. II 7, 17-18): „Quae tibi primum dedit hora nasci,/ Haec mori primum dedit” [„Godzina, w której się urodziłeś, skazała cię na śmierć”], znajdujemy zarówno w poezji, jak i pismach prozatorskich Seneki. Nasuwa się tu zwłaszcza (Seneca Oedipus 988): „pierwszy dzień przesądził o ostatnim”“68; (Seneca Hercules furens 874): „pierwsza godzina dała i odebrała życie”69 oraz (Seneca Consolatio ad Marciam 10, 5): „rodząc się, otrzymał wyrok śmierci”70. Myśl, która pojawia się na końcu utworu (Lyr. II 7, 18-20): „Ille longum/ Vixit, aeternum sibi qui merendo/ Vindicat aevum” [„Ten długo żył, kto zasługuje na życie wieczne”], można z kolei - włącznie z przywołaną już wyżej strofą czwartą (Lyr. II 7, 13-16) odnieść do treści listu 93. Anneusz gani tu ludzi, którzy czyjąś rzekomo przedwczesną śmierć przypisują niesprawiedliwości bogów lub losu (Seneca Epistulae 93, 1-2). Dowodzi następnie, że długość życia, na którą nie mamy wpływu, nie może być

\footnotetext{
64 „Esset aliquod inbecillitatis nostrae solacium rerumque nostrarum si tam tarde perirent cuncta quam fiunt: nunc incrementa lente exeunt, festinatur in damnum".

65 „Nihil privatim, nihil publice stabile est; tam hominum quam urbium fata volvuntur”.

66 "Quidquid longa series multis laboribus, multa deum indulgentia struxit, id unus dies spargit ac dissipat”.

67 „Longam moram dedit malis properantibus qui diem dixit: hora momentumque temporis evertendis imperis sufficit”.

68 „primusque dies dedit extremum”.

69 „prima quae vitam dedit hora carpsit”.

70 „mors enim illi denuntiata nascenti est”. Por. A.J. Boyle, Commentary, w: Seneca, Oedipus, ed., introd., transl., comment. by A.J. Boyle, Oxford 2011, s. 338-339.
} 
kryterium jego wartościowania (Seneca Epistulae 93, 2): „Nie troszczmy się, aby żyć długo, lecz aby żyć dość”. Wystarczająco długo żyje zaś człowiek, który osiąga suwerenność intelektualną czy duchową („przejmuje na sobą władzę”) ${ }^{71}$, utożsamianą też z mądrością (Seneca Epistulae 93, 8): „Pytasz, kiedy żyje się najdłużej? Gdy żyje się aż do osiągnięcia mądrości"72. Człowiek taki zasługuje, by dopuszczono go do grona bogów, a nawet już z nimi przebywał (Seneca Epistulae 93, 10): „Zasłużyłem wszak, by mnie do siebie dopuścili i już pomiędzy nimi byłem, posłałem tam swoją duszę, a oni do mnie swoją"73. Seneka także gdzie indziej wielokrotnie podkreśla, że zachowywanie cnoty wiedzie do nieba, wynosi do rzędu bóstw czy zapewnia nieśmiertelność, na przykład (Seneca Epistulae 73, 15): „Zaufajmy zatem Sekstiuszowi, który wskazuje najpiękniejszą drogę i woła: «Tak idzie się do gwiazd - poprzez wstrzemięźliwość, umiarkowanie, męstwo»" "74; (Seneca Epistulae 18, 13): „Godny boga jest tylko ktoś, kto wzgardził bogactwami”75. Wspomnijmy też, że za człowieka zasługującego na nieśmiertelność Anneusz uważa między innymi Katona (Seneca De tranquillitate 16,4$)$ :

Ego Herculem fleam quod vivus uritur, aut Regulum quod tot clavis configitur, aut Catonem quod vulnera < vulnerat $>$ sua? Omnes isti levi temporis impensa invenerunt quomodo aeterni fierent, et ad inmortalitatem moriendo venerunt.

[Mam opłakiwać Herkulesa, płonącego żywcem, Regulusa, przebitego tyloma gwoźdźmi, Katona, rozwierającego własną ranę? Wszyscy oni w krótkim czasie wynaleźli sposób, aby osiągnąć wieczność, i umierając, stali się nieśmiertelni].

Jak już wspomniano, trzy omówione tu ody z księgi II (5, 6 i 7), w przypadku których obszar poszukiwań dotyczących ich możliwych źródeł inspiracji wytyczyła i pomogła zawęzić refleksja nad specyfiką postaci Katona w utworze II 6, nie są wyjątkowe $^{76} \mathrm{w}$ zbiorze wierszy Sarbiewskiego pod względem widocznych w nich

72 "Quaeris quod sit amplissimum vitae spatium? usque ad sapientiam vivere".

73 "Merui quidem admitti et iam inter illos fui animumque illo meum misi et ad me illi suum miserant”.

74 „Credamus itaque Sextio monstranti pulcherrimum iter et clamanti 'hac «itur ad astra» hac secundum frugalitatem, hac secundum temperantiam, hac secundum fortitudinem"'.

75 „Nemo alius est deo dignus quam qui opes contempsit”. Por. też m.in. Seneca Epistulae 31, 11. Zwróćmy uwagę, że dopiero rejestracja intertekstualności omawianej tu ody pozwala dostrzec obciążenie semantyczne poszczególnych terminów, których znaczenie w innym przypadku może wydawać się „bliżej zresztą nieokreślone”, jak konkluduje np. Krystyna Stawecka (Maciej Kazimierz Sarbiewski. Prozaik i poeta, Lublin 1989, s. 146) w odniesieniu do „zasług” (merendo), od których mówiący w wierszu „uzależnia życie wieczne”.

76 Por. m.in. Lyr. II 10 i Seneca Epistulae 7, 12; 8, 3; 14, 12-13 (przykład aktywności Katona; por. też z mową Porcjusza u Lukana II, 286-305); 24, 6-7 (o Katonie, którego miecz pozostał niesplamiony rzezią - „ab omni caede purum" - nawet podczas wojny domowej); Seneca Consolatio ad Marciam 11, 2-3; także np. Lyr. III 6 (warto wspomnieć - na ten kierunek interpretacji naprowadziła wcześniej E. Buszewicz, Sarmacki Horacy i jego liryka..., s. 159 - że oda zaadresowana „Ad Marcum Silicernium”, biorąc pod 
powinowactw z myślą Seneki. Nie powinno przy tym zaskakiwać, że najwięcej similiów znajdujemy w tekstach prozatorskich Anneusza zalecanych w kolegiach jezuickich do lektury, jak również w jego dramatach, czytanych i omawianych na zajęciach szkolnych ${ }^{77}$. W świetle tych ustaleń wydaje się słuszne, by w dalszych badaniach nad poezją Sarbiewskiego na większą jeszcze niż dotychczas skalę uwzględnić myśl Anneusza jako płaszczyznę możliwych odniesień intertekstualnych. W przypadku wielu utworów poety pozwoliłoby to lepiej wydobyć gamę znaczeniową łacińskich fraz czy ustalić ich optymalne ekwiwalenty eksplikacyjno-przekładowe. Twórczość Sarbiewskiego może być także cennym źródłem w systematycznych badaniach nad recepcją filozoficznej i poetyckiej spuścizny Seneki w kolegiach jezuickich i - szerzej - w kręgu uczestników kultury literackiej dawnej Polski. Podkreślę na koniec, że zaproponowana perspektywa nie oznacza zanegowania słuszności odczytania omówionych tu liryków Sarbiewskiego przede wszystkim w ramach pewnego paradygmatu wartości i symboli kultury chrześcijańskiej czy przez pryzmat duchowości zakonu św. Ignacego ${ }^{78}$, niemniej to właśnie w większości teksty Anneusza wydają

uwagę, że silex to 'skała', może się odnosić właśnie do Marka Katona, którego Seneka określa jako rigidus, 'twardy', podkreślając także wielokrotnie jego wytrzymałość, zob. np. Seneca Epistulae 11, 10; 104, 33; podobnie Lucanus II, 375 i 389; por. s. 6 w tym artykule: ustęp z dzieła Lipsjusza, który pisze o robur Katona Utyckiego - robur to wł. 'twarde drzewo', a metonimicznie m.in. 'twardość') oraz Seneca Epistulae 104, 29-34 (przykład dotyczący Katona); zob. także similia do trzeciej strofy Lyr. II 6, s. 7 w tym artykule. Na kilka Senekańskich similiów do Lyr. III 6 wskazuje także E. Buszewicz, Sarmacki Horacy i jego liryka..., s. 163-166. Lech Bobiatyński (Horacjańskie źródła motywów stoickich w poezji Macieja Kazimierza Sarbiewskiego, w: Watki neostoickie w literaturze polskiego renesansu i baroku, red. P. Urbański, Szczecin 1999, s. 203-210), omawiając odę III 6, uznaje, że Sarbiewski w zakresie obecnych w niej odniesień do tradycji stoickiej podejmuje dialog z Horacym; badacz nie uwzględnia jednak zbieżności pomiędzy poszczególnymi miejscami ody i myślą Senekańską. Inny przykład: Lyr. II 8 oraz Seneca Thyestes 446 - w odniesieniu do formuły adresatywnej „Ad Asterium” (astrum 'gwiazda') można wziąć pod uwagę ustęp dotyczący Katona przypatrującego się światu z dystansu (zob. s. 14-15 w tym artykule), passusy, w których mowa o wyniesieniu do gwiazd przez cnotę (zob. s. 19 w tym artykule) i wzmiankę o „Scypionach i Katonach” oczekujących wśród gwiazd na zmarłego syna Marcji - Seneca Consolatio ad Marciam 25, 2. Zob. poza tym Senekańskie similia do innych liryków wymienione przez Elwirę Buszewicz (Sarmacki Horacy i jego liryka..., s. 177-179, 235-237). Zob. Catalogus quinquennalis..., s. 6, i Catalogus perpetuus..., s. 25-29, oraz Catalogus triennalis..., s. 911-919.

78 Jak proponuje Piotr Urbański (Wobec duchowości Ignacjańskiej, w: idem, Theologia fabulosa..., s. 86-96). Autor Między ignacjanizmem a neostoicyzmem (s. 99-114) sam zwraca zresztą uwagę na trudność tej kwestii. W odniesieniu do wielu konceptów Sarbiewskiego rzeczywiście niełatwo rozstrzygnąć, czy należałoby w ich przypadku mówić o nacechowaniu perspektywą ignacjańską, czy raczej o inspiracji myślą Seneki - o ile daje się ona pogodzić z paradygmatem wartości określanych jako chrześcijańskie. Notabene za Senekańskie koncepty - by uzupełnić uwagi badacza - można uznać także np. przeciwstawienie rozgłosu zyskanego u pospólstwa rzeczywistemu poznaniu samego siebie (por. similia do Lyr. II $10 \mathrm{w}$ przyp. $76 \mathrm{w}$ tym artykule); zdefiniowanie wystarczającej długości życia jako takiej, która pomaga osiągnąć życie wieczne (zob. similia do Lyr. II 7, s. 18-19 w tym artykule); zachętę, by nie pokładać nadziei w orężu, lecz przez przybranie postawy całkowicie panującego nad sobą mędrca króla wzgardzić wszelkim zewnętrznym zagrożeniem (por. Lyr. IV 3, 5-24 i Seneca Thyestes 344-390). Ze względu na liczne similia między Lyr. II 5 a pewną liczbą miejsc Anneuszowej prozy i poezji (zob. 
się (tu i wielu innych przypadkach) dostarczać poecie konceptualno-językowego tworzywa $^{79}$, które - zgodnie z zaleceniami mistrza - godziło mu się wykorzystać bez jednoczesnego przyjmowania zobowiązań wobec pogańskiej szkoły filozoficznej i całokształtu głoszonych przez nią nauk ${ }^{80}$.

\section{Bibliografia}

\section{Źródła}

Skróty

Augustinus De civitate Dei - S. Aurelius Augustinus, De civitate Dei libri XXII, w: S. Aurelius Augustinus, Opera omnia, acc. J.-P. Migne, Paris 1845 (Patrologiae Cursus Completus. Series Latina $[\mathrm{PL}], 41)$.

Cicero Ad Atticum - Cicero, Letters to Atticus, transl. by D.R. Shackleton Bailey, vol. 5, Cambridge 1966.

Cicero Brutus - M. Tullius Cicero, Scripta quae manserunt omnia, fasc. 4: Brutus, rec. H. Malcovati, Leipzig 1970.

Cicero De divinatione - M. Tullius Cicero, Scripta quae manserunt omnia, fasc. 6: De divinatione. De fato. Timaeus, ed. R. Giomini, Leipzig 1975.

Cicero De finibus bonorum et malorum - M. Tullius Cicero, De finibus bonorum et malorum libri quinque, rec. C.F.W. Müller, Leipzig 1908.

Cicero De legibus - w: M. Tullius Cicero, De re publica. De legibus. Cato Maior de senectute. Laelius de amicitia, rec. J.G.F. Powell, Oxford 2006.

Cicero De officiis - M. Tullius Cicero, De officiis, rec. M. Winterbottom, Oxford 1994.

Cicero Orator - M. Tullius Cicero, Scripta quae manserunt omnia, fasc. 5: Orator, ed. R. Westman, Leipzig 1980.

Cicero Paradoxa stoicorum - w: M. Tullius Cicero, Paradoxa stoicorum. Academicorum reliquae cum Lucullo. Timaeus. De natura deorum. De divinatione. De fato, ed. O. Plasberg, Leipzig 1908.

s. 13-17 w tym artykule) jestem też sceptyczna co do słuszności upatrywania w tej odzie świadectwa recepcji tradycji hermetycznej, a sceptycyzm ten wzmacniają krytyczne uwagi, które w odniesieniu do takiej interpretacji formułuje Piotr Urbański (E rebus humanis excessus. Sarbiewski i tradycja hermetyczna, w: idem, Theologia fabulosa..., s. 117-121).

79 Znajdziemy tu niejednokrotnie również inne inspiracje, zwłaszcza Horacjańskie - zob. np. uwagę Elwiry Buszewicz (Sarmacki Horacy i jego liryka..., s. 189-190) w odniesieniu do Lyr. II 5, 54.

so Por. s. 12-13 w tym artykule. Notabene Sarbiewski unika odwołań do tego rodzaju Senekańskich twierdzeń, które otwarcie kolidowałyby z systemem wartości chrześcijańskich, o czym możemy się przekonać zwłaszcza podczas lektury ody Cato Politicus. Brak tam odniesień do samobójczej śmierci rzymskiego herosa - aktu bardzo mocno skojarzonego z postacią Katona Utyckiego (por. s. 3 i przyp. 9 w tym artykule) i przez wielu autorów, w tym przez Senekę (zob. np. Epistulae 13, 14; 24, 6-8; 67, 13; 95, 72; 104, 29-33), podniesionego do rangi wyrazistego symbolu stoickiej niezawisłości. 
Cicero Pro Sestio - w: M. Tullius Cicero, Orationes, rec. G. Peterson, Oxford 1910.

Cicero Tusculanae disputationes - M. Tullius Cicero, Tusculanae disputationes, ed. M. Giusta, Torino 1984.

Hieronymus Epistolae - S. Eusebius Hienorymus, Epistolae in quattuor classes divisae secundum ordinem temporum, w: S. Eusebius Hienorymus, Opera omnia, acc. J.-P. Migne, Paris 1845 (Patrologiae Cursus Completus. Series Latina, 22).

Horatius Carmina - w: Q. Horatius Flaccus, Opera, ed. S. Borzsák, Leipzig 1984.

Horatius Epistulae - w: Q. Horatius Flaccus, Opera, ed. S. Borzsák, Leipzig 1984.

Lactantius Divinae institutiones - L. Caecilius Firmianus Lactantius, Divinarum institutionum libri septem, w: L. Caecilius Firmianus Lactantius, Opera omnia, acc. J.-P. Migne, Paris 1844 (Patrologiae Cursus Completus. Series Latina, 6).

Lucanus - M. Annaeus Lucanus, De bello civili libri X, ed. D.R. Shackleton Bailey, Stuttgart 1988. Lyr. - M.K. Sarbiewski, Liryki oraz Droga rzymska i fragment Lechiady, przeł. T. Karyłowski, oprac. M. Korolko przy współudziale J. Okonia, Warszawa 1980.

Plutarchus Cato Maior - w: Plutarch, Lives, transl. by B. Perrin, vol. 2, Cambridge (MA)-London 1968 (Loeb Classical Library, 47) [1. wyd. 1914].

Plutarchus Cato Minor - w: Plutarch, Lives, transl. by B. Perrin, vol. 8, Cambridge (MA)-London 1959 (Loeb Classical Library, 100) [1. wyd. 1919].

Pseudo-Seneca Octavia - w: L. Annaeus Seneca, Tragoediae. Incertorum auctorum Hercules (Oetaeus). Octavia, rec. O. Zwierlein, Oxford 1986.

Sallustius Catilinae coniuratio - w: C. Sallustius Crispus, Catilina. Iugurtha. Fragmenta ampliora, ed. A. Kurfess, Leipzig 1981.

Seneca Consolatio ad Helviam - w: L. Annaeus Seneca, Dialogorum libri duodecim, rec. L.D. Reynolds, Oxford 1977.

Seneca Consolatio ad Marciam - w: L. Annaeus Seneca, Dialogorum libri duodecim, rec. L.D. Reynolds, Oxford 1977.

Seneca De providentia - w: L. Annaeus Seneca, Dialogorum libri duodecim, rec. L.D. Reynolds, Oxford 1977.

Seneca De tranquillitate - L. Annaeus Seneca, De tranquillitate animi, w: L. Annaeus Seneca, Dialogorum libri duodecim, rec. L.D. Reynolds, Oxford 1977.

Seneca Epistulae - L. Annaeus Seneca, Ad Lucilium epistulae morales, rec. L.D. Reynolds, Oxford 1965.

Seneca Hercules furens - w: L. Annaeus Seneca, Tragoediae. Incertorum auctorum Hercules (Oetaeus). Octavia, rec. O. Zwierlein, Oxford 1986.

Seneca Naturales quaestiones - L. Annaeus Seneca, Naturalium quaestionum libri, rec. H.M. Hine, Stuttgart-Leipzig 1996.

Seneca Oedipus - L. Annaeus Seneca, Edyp. Oedipus, wstęp, edycja, przekład i komentarz T. Sapota, I. Słomak, Katowice 2017.

Seneca Phoenissae - L. Annaeus Seneca, Phoenissae. Kobiety fenickie, w: T. Sapota, I. Słomak, Kobiety fenickie Lucjusza Anneusza Seneki. Opracowanie monograficzne, Katowice 2019. Seneca Thyestes - w: L. Annaeus Seneca, Tragoediae. Incertorum auctorum Hercules (Oetaeus). Octavia, rec. O. Zwierlein, Oxford 1986. 
Servius - Servius Grammaticus, Qui feruntur in Vergilii carmina commentarii, rec. G. Thilo, vol. 2, Leipzig 1884.

Valerius Maximus - Valerius Maximus, Memorable Doings and Sayings, vol. 1-2, ed. and transl. by D.R. Shackleton Bailey, Cambridge (MA)-London 2000 (Loeb Classical Library, 492-493).

Velleius Paterculus - Velleius Paterculus, Historiarum ad M. Vinicium consulem libri duo, rec. W.S. Watt, Leipzig 1988.

Vergilius Aeneis - w: P. Vergilius Maro, Opera, rec. R.A.B. Mynors, Oxford 1969.

\section{Pozostałe źródła}

Catalogus triennalis [1614-1622], w: Ordinationes praepositorum generalium, provincialium, visitatorum et responsa Romana Provinciae Polonae et Litvaniae saeculis XVI-XVII data, Archivum Societatis Iesu Cracoviense, 496, s. 910-919.

Kochanowski J., Fraszki, oprac. J. Pelc, Wrocław 1991.

Libri caniculares [1604], Catalogus quinquennalis [1604-1608], Catalogus commentariorum 1604, Catalogus perpetuus [1629-1934], Index horum librorum, qui non solum praelectiones in scholis adiuvant, sed etiam plurimum conferunt ad eruditionem comparandam [1604], w: G.M. Pachtler, Ratio studiorum et institutiones scholasticae Societatis Iesu per Germaniam olim vigentes collectae, concinnatae, dilucidatae, Berlin 1894, vol. 4, s. 2-3; 5-17; 18-19, 25-29.

Lipsius I., Monita et exempla politica, Antwerpen: Ioannes Moretus, 1605.

Mickiewicz A., Pan Tadeusz, oprac. K. Górski, Warszawa 1983.

Sarbiewski M.K., Wykłady poetyki. Praecepta poetica, przeł. i oprac. S. Skimina, Wrocław 1958.

\section{Opracowania}

Armisen-Marchetti M., Sapientiae facies. Étude sur les images de Sénèque, Paris 1989.

Bobiatyński L., Horacjańskie źródła motywów stoickich w poezji Macieja Kazimierza Sarbiewskiego, w: Wątki neostoickie w literaturze polskiego renesansu i baroku, red. P. Urbański, Szczecin 1999, s. 191-210.

Boyle A.J., Commentary, w: Seneca, Oedipus, ed., introd., transl., comment. by A.J. Boyle, Oxford 2011.

Buszewicz E., Maciej Kazimierz Sarbiewski - „Ody” refleksyjne i religijne, w: Lektury polonistyczne, red. J.S. Gruchała, Kraków 1999, s. 112-137.

Buszewicz E., Sarmacki Horacy i jego liryka. Imitacja - gatunek - styl. Rzecz o poezji Macieja Kazimierza Sarbiewskiego, Kraków 2006.

Christian L.G., Theatrum Mundi: The History of an Idea, New York-London 1987.

Goar R.J., The Legend of Cato Uticensis from the First Century B.C. to the Fifth Century A.D. With an Appendix on Dante and Cato, Bruxelles 1987.

Pelc J., Jan Kochanowski. Szczyt renesansu w literaturze polskiej, Warszawa 1980.

Sapota T., Słomak I., „Kobiety fenickie” Lucjusza Anneusza Seneki. Opracowanie monograficzne, Katowice 2019. 
Sapota T., Słomak I., Komentarz, w: L. Annaeus Seneca, Edyp. Oedipus, wstęp, edycja, przekład i komentarz T. Sapota, I. Słomak, Katowice 2017.

Stawecka K., Maciej Kazimierz Sarbiewski. Prozaik i poeta, Lublin 1989.

Urbański P., E rebus humanis excessus. Sarbiewski i tradycja hermetyczna, w: P. Urbański, Theologia fabulosa. Commentationes Sarbievianae, Szczecin 2000, s. 115-128.

Urbański P., Między ignacjanizmem a neostoicyzmem, w: P. Urbański, Theologia fabulosa. Commentationes Sarbievianae, Szczecin 2000, s. 97-114.

Urbański P., Wobec duchowości Ignacjańskiej, w: P. Urbański, Theologia fabulosa. Commentationes Sarbievianae, Szczecin 2000, s. 83-96.

\section{IWONA SŁOMAK}

仓) Uniwersytet Śląski, Katowice / University of Silesia, Katowice, Poland

@ iwona.slomak[at]us.edu.pl

(D) https://orcid.org/0000-0002-6940-9520

Iwona Słomak - Associate Professor, University of Silesia, Faculty of Humanities, Institute of Literary Studies. Research interest: poetics, rhetoric, ancient and Neo-Latin drama, reception of ancient literature. Recent publications: Denis Petau, Carthaginenses. Kartaginczycy (edition with translation and commentary, 2019); Kobiety fenickie Lucjusza Anneusza Seneki. Opracowanie monograficzne (2019; with Tomasz Sapota); "Tragedy According to Jacobus Pontanus and the Tradition of Antiquity", Terminus 22 (2020), issue 3(56); "'Phoenissae, 'Phoenissa, 'Thebais': The Title of Seneca’s Phoenician Women", Philologia Classica 15 (2020), fasc. 1 (with Tomasz Sapota).

This research received no specific funding. 